\title{
Above-ground biomass yields at different densities of honey mesquite
}

\author{
JOHN D. LAXSON, WALTER H. SCHACHT, AND M. KEITH OWENS
}

\begin{abstract}
Authors are former graduate student, Agriculture Department, Angelo State University, San Angelo, Tex. 76909; assistant professor, Department of
\end{abstract} Agronomy, University of Nebraska, Lincoln, Neb. 68583-0915; and associate professor, Texas Agriculture Experiment Station, Uvalde, Tex. $78801-9151$.

\begin{abstract}
Dense stands of honey mesquite (Prosopis glandulosa Torr. var. glandulosa) negatively impact livestock handling and herbaceous forage production; however, very little information is available on the effect of stand density on biomass production of herbage and wood. Our study compared above-ground yields of herbage and wood in undisturbed, cleared, and 3 levels of thinned $(100$, 300 , and 900 stems ha-1) stands of mesquite. Total removal of the mesquite canopy resulted in a $45 \%$ increase in herbaceous standing crop compared to the control in the first 2 years post-clearing. Herbage yields for the thinning treatments were intermediate although herbage yields for the 900 stems ha $\left(2,017 \mathrm{~kg} \mathrm{ha}^{-1}\right)$ treatment was similar $(P>0.1)$ to the control $\left(1,849 \mathrm{~kg} \mathrm{ha}^{-1}\right)$ and lower $(P<0.1)$ than the cleared treatment $\left(2,684 \mathrm{~kg} \mathrm{ha}^{-1}\right)$. Total wood production was significantly $(P<0.1)$ lower for the 3 thinned treatments $\left(481\right.$ to $\left.1,214 \mathrm{~kg} \mathrm{ha}^{-1} \mathrm{yr}^{-1}\right)$ than the control $\left(8,128 \mathrm{~kg} \mathrm{ha}^{-1} \mathrm{yr}^{-1}\right)$ because of the higher stem density for the control $\left(>7,500\right.$ stems $\left.\mathrm{ha}^{-1}\right)$. Growth rates of individual mesquite stems were 2- to 3-fold greater $(P<0.1)$ for the 100 and 300 stem $\mathrm{ha}^{-1}$ stands than for the higher-density stands during the relatively wet growing season of 1992 . Under the drier 1993 conditions, however, growth rates were similar $(P>0.1)$ for all treatments. Results indicated that severe thinning to less than 900 stems ha $^{-1}$ increased the amount of available forage and positively influenced the potential growth rates of the remaining mesquite stems.
\end{abstract}

Key Words: agroforestry, Prosopis glandulosa, tree growth rates, semi-arid woodland

Honey mesquite (Prosopis glandulosa Torr. var. glandulosa) dominates much of the rangeland in western Texas, New Mexico, Arizona, and regions of Mexico and can occur at densities as high as 10,000 stems ha ${ }^{-1}$ (McPherson and Wright 1986). Mesquite is prevalent on about 23 million ha of rangeland in Texas and is generally considered the most troublesome woody plant species in the state (Scifres 1980). Mesquite is a prolific producer of long-lived seeds that germinate readily after scarification. It establishes under a wide range of conditions and withstands repeated top removal (Weltzin 1990).

Research was funded by the Management, Instruction, and Research Center, Angelo State University. Valuable assistance was provided by C.B. Scott, C.S. MoCown, and K.R. Shaffer.

Manuscript accepted 22 Dec. 1996.
Dense stands of mesquite negatively impact livestock handling and herbaceous forage production. Results from numerous studies (Dahl et al. 1978, Gibbens et al. 1986, Dugas and Mayeux 1991, Heitschmidt and Dowhower 1991) have shown increased herbaceous plant production in response to mesquite control. Overstory/understory relations in mesquite woodland, however, have not been studied in detail. For instance, effects of stand age, different levels of canopy cover, and mesquite density on understory production have not been quantified. In addition, limited information is available on the production and growth rate response of honey mesquite trees to such management practices as thinning (Cornejo-Oviedo et al. 1991). Mesquite trees have the potential to grow at favorable rates and to produce good quality wood appropriate for various markets (Felker et al. 1990). Mesquite is valued as firewood and barbecuewood as well as lumber for the furniture and flooring industry.

The objectives of this study were to (1) determine biomass yields of wood and herbage at 5 levels of honey mesquite density and (2) determine the growth rate of mesquite trees at 5 different stand densities.

\section{Materials and Methods}

\section{Study Site Description}

This study was conducted in the Rolling Plains resource area at the Angelo State University Management, Instruction, and Research (MIR) Center about $10 \mathrm{~km}$ northwest of San Angelo, Texas $\left(31^{\circ} 30^{\prime} \mathrm{N} ; 100^{\circ} 30^{\prime} \mathrm{W}\right)$. Climate on the study area is semiarid. Average annual precipitation is $519 \mathrm{~mm}$, with most of the precipitation occurring between April and October as a result of thunderstorm activity. The average annual temperature is $18.3^{\circ} \mathrm{C}$ with an average frost-free period of 232 days (Wiedenfeld and Flores 1976).

Soils at the site are Angelo clay loams (fine-silty, mixed, thermic Aridic Calciustolls). The Angelo series consists of very deep, well drained, moderately slow permeable soils formed in calcareous loamy and clayey materials. These level- to gently-sloping upland soils have slopes ranging from 0 to $3 \%$ (USDA 1989).

Vegetation of the site was dominated by a dense stand of honey mesquite which had regrown since being top killed by a wildfire in 1968. Maximum stem age at the time of the study was about 25 years. In this study, a woody shoot emerging at ground level with a basal diameter greater than $1 \mathrm{~cm}$ was considered a stem. Density of the stand was $7,630 \pm 490$ (SE) stems ha ${ }^{-1}$, with about 
1.5 stems tree ${ }^{-1}$. The majority of the trees had a single stem but multiple-stemmed trees also were common. Stems of multiplestemmed trees joined at a common base at or below ground level. Most of the older trees that regrew from root crowns following the fire had self-thinned to 1 to 4 stems. Younger trees had single stems and had grown from seed. Herbaceous understory vegetation was dominated by cool-season grasses, primarily Texas wintergrass (Stipa leucotricha Trin. and Rupr.). The major forb species were annuals such as wooly indianwheat (Plantago patagonica Jacq.), southern thistle (Chichorium texanum Buckl.), and annual broomweed (Amphiachyris drancunculoides (DC.) Nutt.), although perennial forbs such as ragweed (Ambrosia spp.) also were common.

\section{Treatments}

The 5.5-ha area was divided into 3 blocks, based on surface drainage and vegetation composition. Five 0.36-ha plots were delineated within each block and randomly assigned to 1 of 5 treatments: (1) cleared; (2) thinned to 100 stems ha $^{-1}$ (10-m spacing); (3) thinned to 300 stems $^{-1} \mathrm{~s}^{-1}(5.8-\mathrm{m}$ spacing); (4) thinned to 900 stems ha $^{-1}$ (3.3-m spacing); and (5) control (7,630 stems ha $\left.{ }^{-1}\right)$. Treatments were applied in autumn 1991 with chain saws. In the thinning process, the largest and straightest stems were left at the specified spacing for each treatment. Over $90 \%$ of the selected stems in the 100 and 300 stems ha $^{-1}$ treatments were larger than 9 $\mathrm{cm}$ in basal diameter. Basal diameter of about $40 \%$ of the select-

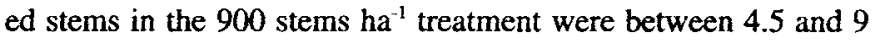
$\mathrm{cm}$, and the other $60 \%$ were over $9 \mathrm{~cm}$. Felled trees were cut at ground level and removed from the plots. The cut basal surface of each stem was treated with a 2:98 (1c) mixture of the butoxyethyl ester of triclopyr $\{[3,5,6,-$ trichloro-2-pyridinyl)oxy $\}$ acetic acid $\}$ and diesel fuel to prevent resprouting. Treatment of stumps was not totally effective and resprouting from treated stumps was common. Furthermore, populations of mesquite seedlings established each year on the thinned and cleared plots. Annual lowvolume basal [triclopyr + diesel $(5: 95$ 1c) mixture] or foliar spraying $[0.75 \%$ clopyralid (3,6-dichloro-2-pyridinecarboxylic acid) in water] during the summer was necessary to control the new mesquite growth.

A ditching machine was used in January 1993 to sever mesquite roots to a depth of $1 \mathrm{~m}$ along the perimeter of all plots. The objective of this activity was to minimize the effect of lateral roots from mesquite trees on neighboring plots. The lateral root system of mesquite trees is concentrated in the top $0.3 \mathrm{~m}$ of the soil (Heitschmidt et al. 1988).

\section{Vegetation Sampling}

Herbaceous biomass was sampled in April and August of 1992 and 1993 to estimate standing crop yields. The April sampling period coincided with maturation of cool-season grasses, while sampling in August coincided with maturation of dominant warm-season grasses and forbs. Herbaceous vegetation was harvested at ground level within 10 randomly-placed $0.33-\mathrm{m}^{2}$ quadrats in each plot. Plant material was separated by species, individually sacked, dried in a forced-air oven at $60^{\circ} \mathrm{C}$ for 72 hours, and weighed.

Annual wood production (including stem wood, branches, and bark) of trees was estimated within 2 size classes ( 4.5 to $9 \mathrm{~cm}$ and $>9 \mathrm{~cm}$ basal diameter) for the 3 thinned treatments and control.
The basal diameter of 16 randomly selected stems in each sizeclass was measured at ground level with a diameter tape in each plot in February 1992. Each selected stem was marked by securing a numbered metal tag to it at $0.6 \mathrm{~m}$ above ground. Stems were remeasured at ground level in January 1993 and October 1993. Because fewer than $10 \%$ of the stems in the 100 stems ha $^{-1}$ and 300 stems ha ${ }^{-1}$ treatments had basal diameters less than $9 \mathrm{~cm}$, only stems in size class $2(>9 \mathrm{~cm})$ were measured. Both sizeclasses were represented in the 900 stems ha $^{-1}$ and control plots, and 16 stems in each size-class were marked and measured in each plot. Stems smaller than size-class 1 were not marked and measured in the control plots even though their density was over 2,500 stems ha $^{-1}$. These stems were in the understory, generally less than $2 \mathrm{~cm}$ in basal diameter, and appeared to represent an insignificant part of total wood production.

In December 1992, the basal diameter of 35 individual stems with a range of basal diameters from 4 to $25 \mathrm{~cm}$ were selected in an area adjacent to the study site. Trees were felled, sectioned for ease of handling, and weighed to the nearest $0.1 \mathrm{~kg}$. Subsamples were dried in a forced-air oven to determine the percentage dry matter. These data were used to develop a regression equation relating oven-dry wood biomass to basal area. The prediction equation was $\mathrm{Y}=-3.39+.215 \mathrm{X}\left(\mathrm{r}^{2}=0.967\right)$, where $\mathrm{Y}$ was wood biomass $(\mathrm{kg})$ and $\mathrm{X}$ was the basal area $\left(\mathrm{cm}^{2}\right)$. This equation, similar to that of Cornejo-Oviedo et al. (1991), was used to estimate woody biomass production of marked trees within each thinned treatment. Estimates of annual wood biomass production were based on difference in total wood biomass in successive years. Basal diameters of 18 individual stems (ranging from 4 to $24 \mathrm{~cm}$ ) were measured during July 1992 in an adjacent, dense stand of mesquite to describe the relation between basal diameter and leaf biomass of mesquite. Leaves of each stem were stripped, dried in a forced-air oven at $60^{\circ} \mathrm{C}$ for 72 hours and weighed. The resulting regression equation was $Y=1413.92+244.94 X$, where $Y$ was mesquite leaf biomass $(\mathrm{g})$ and $\mathrm{X}$ was basal diameter $\left(r^{2}=0.927\right)$.

Canopy cover was estimated by line intercept. Mesquite canopy was measured along five $15-\mathrm{m}$ lines randomly located in each plot in August 1993.

\section{Statistical Analysis}

Herbaceous plant standing crop and annual wood production were analyzed as randomized block ANOVAs with thinning treatment as the main effect and individual plots $(n=3)$ as blocks. Stem growth data expressed as basal-diameter increment were analyzed as a split-plot with block and thinning treatment in the main plot and size class as the sub-plot. Analysis of variance of individual stem data showed that basal-diameter increments differed by size-class. Analysis of variance for individual stem parameters was then conducted within size-class with thinning treatment as the main effect and individual plots as blocks. Repeated-measures analysis (Winer 1971) was used because measurements were made on the same trees over a 2-year period. Data were analyzed within the framework of General Linear Models of SAS (SAS 1988). Least squares analysis was performed and the protected LSD procedure was used to detect differences among treatment means when appropriate (Steel and Torrie 1980). Significant year differences were identified using a univariate analysis procedure for paired contrasts between years (SAS 1988). Because of inherently high degree of variability within the mesquite woodland type, a 0.1 significance level was considered appropriate for testing differences. 


\section{Results and Discussion}

Precipitation from September 1991 through August 1992 was $150 \%$ of the long-term average (Fig. 1). Rainfall was particularly favorable from December 1991 through February 1992. The fall and early winter of 1992-93 (September through January) were relatively dry and precipitation from February through August 1993 was near the long-term average.

\section{Herbaceous Plant Standing Crop}

Total removal of mesquite canopy resulted in a $45 \%$ increase in herbaceous plant standing crop compared to controls (Table 1). The increase in herbaceous standing crop is in the same range reported for other sites in Texas (Scifres and Polk 1974, Bedunah and Sosebee 1984, Heitschmidt and Dowhower 1991). Herbaceous standing crop for the cleared treatment was similar (P > 0.1) to standing crop at either 100 or $300 \mathrm{stems} \mathrm{ha}^{-1}$ but greater $(\mathrm{P}<0.1)$ than the herbaceous standing crop at 900 stems $\mathrm{ha}^{-1}$. Compared to the cleared treatment, mean herbaceous standing crop was significantly $(\mathrm{P}<0.1)$ decreased at a mesquite density between 300 and 900 stems ha $^{-1}$. This range in density is equivalent to canopy cover ranging from $37 \%$ (300 stems ha $\left.{ }^{-1}\right)$ to $61 \%$ (900 stems ha $\left.{ }^{-1}\right)$.

An interaction $(P<0.1)$ between treatment and year of observation affected biomass of total grasses. Total grass biomass for the cleared treatment in 1993 was greater $(P<0.1)$ than on the thinned and undisturbed plots, but there was no treatment effect $(\mathrm{P}>0.1)$ in 1992 (Table 1). Yields of warm-season grasses in 1992 and 1993 followed a pattern similar to total grasses. Biomass of warm-season grasses on the cleared plots in 1993 was double that in 1992 whereas 1993 yields for the other 4 treatments were only half of the 1992 levels. Growth of warm-season grasses in 1993 on cleared areas was favorcd by removal of mesquite trees, high light intensity, and adequate summer precipitation. The principal warm-season grasses were buffalograss [Buchloe dactyloides (Nutt.) Engelm] and sand dropseed [Sporobolus cryptandrus (Torr.) A. Gray]. Warm-season grass yields represented a small portion $(<20 \%)$ of total herbaceous plant production except in the cleared treatment in 1993 (Table 1).

Standing crop yields of cool-season grasses were not affected ( $\mathrm{P}>0.1$ ) by treatment (Table 1), but yields were 6-fold higher $(\mathrm{P}<0.1)$ in $1992\left(2,831 \mathrm{~kg} \mathrm{ha}^{-1}\right)$ than in $1993\left(474 \mathrm{~kg} \mathrm{ha}^{-1}\right)$ averaged across treatments. The unusually high precipitation received in late 1991 and early 1992 coupled with the mild 1991-92 winter favored growth of the dominant cool-season grasses even in the reduced-canopy treatments. The winter of

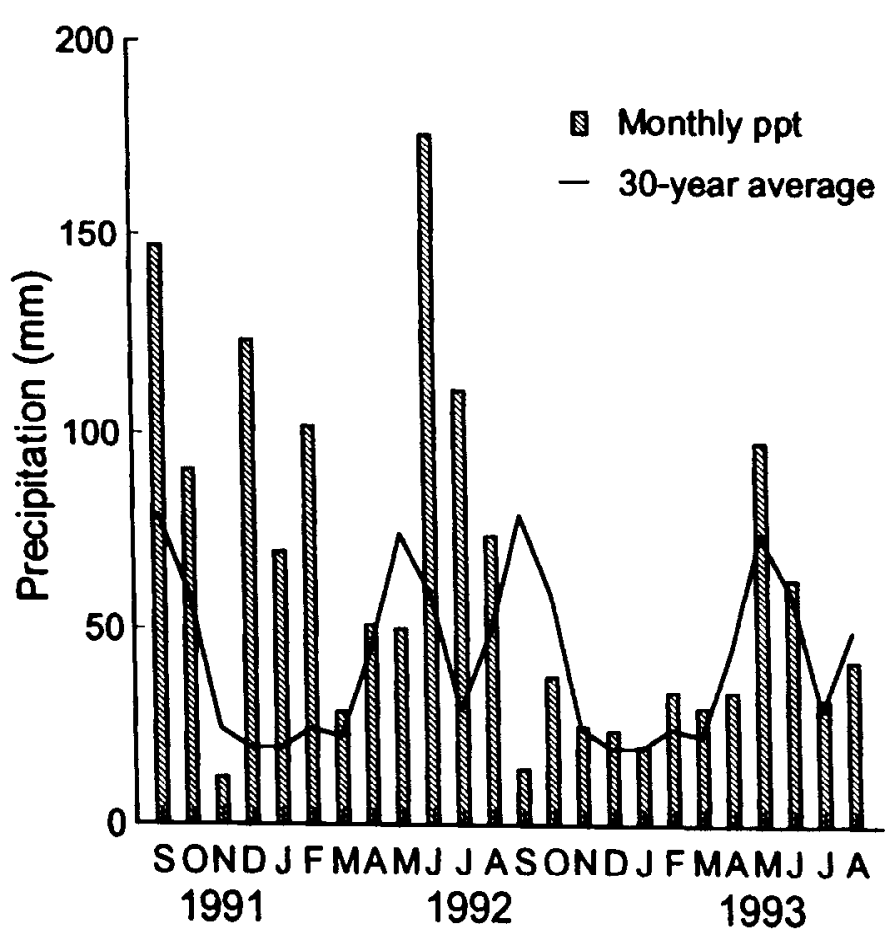

Fig. 1. Monthly precipitation from September 1991 through August 1993 compared to the 30-year average for San Angelo, Tex.

1993 was relatively dry, and cool-season grass yields were low. Cool-season grasses were the dominant species for all treatments composing from $64 \%$ (cleared) to $83 \%$ (900 stems ha ${ }^{-1}$ ) of herbaceous yields. Texas wintergrass was the dominant coolseason grass in 1992 and 1993, whereas little barley (Hordeum pussillum Nutt.) and rescuegrass [Bromus unioloides (Willd.) H.B.K.] were prevalent only in 1992. Little barley and rescuegrass are annuals that are indicative of favorable moisture conditions.

Forb yields were extremely variable within treatment and differences $(P>0.1)$ were not detected (Table 1); however, yields differed $(P<0.1)$ between $1992\left(666 \mathrm{~kg} \mathrm{ha}^{-1}\right)$ and $1993(229 \mathrm{~kg}$ $\left.\mathrm{ha}^{-1}\right)$ averaged across treatments. The dominant forbs in 1992 on all plots were cool-season species, e.g., wooly indianwheat and southern thistle, whereas warm-season forb species, e.g., annual broomweed and ragweed (Ambrosia spp.) were dominant in 1993.

Table 1. Mean standing crop of the major components of herbaceous vegetation for 1992 and 1993 at 5 mesquite densities, San Angelo, Tex.

\begin{tabular}{|c|c|c|c|c|c|c|c|}
\hline \multirow[b]{2}{*}{ Treatment } & \multirow{2}{*}{$\begin{array}{c}\text { Total }^{1} \\
\text { herbaceous } \\
92 / 93\end{array}$} & \multicolumn{2}{|c|}{$\begin{array}{c}\text { Total } \\
\text { grasses }\end{array}$} & \multicolumn{2}{|c|}{$\begin{array}{c}\text { Warm-season } \\
\text { grasses }\end{array}$} & \multirow{2}{*}{$\begin{array}{c}\text { Cool-season } \\
\text { grasses } \\
92 / 93\end{array}$} & \multirow{2}{*}{$\begin{array}{l}\text { Total } \\
\text { forbs }^{1} \\
92 / 93\end{array}$} \\
\hline & & 92 & 93 & 92 & 93 & & \\
\hline & \multicolumn{7}{|c|}{ 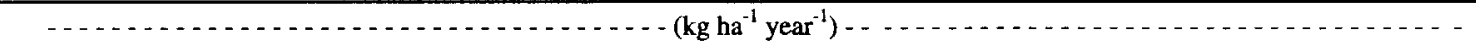 } \\
\hline Cleared & $2,684^{a}$ & $2,985^{\mathbf{a}}$ & $954^{\mathrm{a}}$ & $156^{\mathrm{a}}$ & $321^{a}$ & $1,731^{\mathrm{a}}$ & $715^{\mathrm{a}}$ \\
\hline 100 stems ha $^{-1}$ & $2,147^{\text {ab }}$ & $3,152^{\mathbf{2}}$ & $461^{b}$ & $84^{a}$ & $40^{b}$ & $1,745^{\mathrm{a}}$ & $341^{\mathrm{a}}$ \\
\hline 300 stems ha ${ }^{-1}$ & $2,314^{a b}$ & $3,060^{a}$ & $535^{\mathrm{b}}$ & $68^{a}$ & $21^{b}$ & $1,753^{\mathrm{a}}$ & $517^{a}$ \\
\hline 900 stems ha ${ }^{-1}$ & $2,017^{b}$ & $2,958^{\mathrm{a}}$ & $473^{b}$ & $54^{\mathrm{a}}$ & $30^{\mathrm{b}}$ & $1,674^{\mathrm{a}}$ & $301^{a}$ \\
\hline Control & $1,849^{\mathrm{b}}$ & $2,521^{\mathrm{a}}$ & $446^{\mathrm{b}}$ & $157^{\mathrm{a}}$ & $89^{b}$ & $1,361^{\mathrm{a}}$ & $366^{\mathrm{a}}$ \\
\hline
\end{tabular}

Standing crops of total herbaceous, cool-season grasses, and total forbs are not presented by year because there were not treatment $X$ year interactions $(P>0.1)$.

${ }^{2}$ Standing crops of total grasses and warm-season grasses are presented by year because of treatment $x$ year interactions $(P<0.1)$.

Means within columns with different superscripts are significantly different $(P<0.1)$. 


\section{Honey Mesquite Stem Growth}

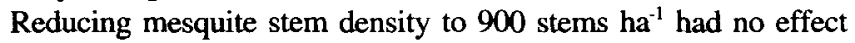
$(\mathrm{P}>0.1)$ on basal diameter growth rates of stems in size-class 1 (4.5 to 9-cm diameter) compared to growth rates of stems in the control (Table 2). Basal-diameter growth rates were similar $(\mathrm{P}>0.1)$ in $1992(0.35 \mathrm{~cm})$ and $1993(0.4 \mathrm{~cm})$, indicating that differences in amount of precipitation did not affect wood growth of stems in sizeclass 1.

Growth rates of mesquite stems in size-class $2(>9 \mathrm{~cm})$ were affected $(\mathrm{P}<0.1)$ by an interaction between the thinning treatment and the year of observation. During the relatively wet growing season of 1992, basal diameter increment of the larger stems was 2 - to 3 -fold higher $(P<0.1)$ for the lower mesquite densities (100 and 300 stems ha $^{-1}$ ) than for the 900 stems ha $^{-1}$ and control stands (Table 2). Under the drier 1993 conditions, however, growth rates were similar $(\mathrm{P}>0.1)$ for all treatments. At lower mesquite densities, basal-diameter growth rates for stems in sizeclass 2 were nearly twice as high in 1992 as in 1993. Basal-diameter growth rates of the stems at the higher stand densities did not differ greatly between years. Cornejo-Oviedo et al. (1992) reported first-year growth rates of $0.97 \mathrm{~cm} \mathrm{stem}^{-1}$ in plots with 100 mesquite trees ha $\mathrm{ha}^{-1}$ and $0.49 \mathrm{~cm} \mathrm{stem}^{-1}$ in plots with 1,740 trees $\mathrm{ha}^{-1}$ in southern Texas. Tree growth rates on the control plots in 1992 and 1993 were similar to those reported by Cornejo-Oviedo et al. (1992).

Table 2. Mean basal diameter increment by size-class ${ }^{1}$ for 1992 and 1993 at 4 mesquite densities, San Angelo, Tex.

\begin{tabular}{lccc}
\hline \hline $\begin{array}{l}\text { Mesquite density } \\
\text { stems ha }^{-1} \text { ) }\end{array}$ & ${\text { Size-class } 1^{2}}^{1992 / 1993}$ & \multicolumn{2}{c}{ Size-class $2^{3}$} \\
\hline & 1992 & 1993 \\
100 & - & $1.3^{\mathrm{a}}$ & $0.7^{\mathrm{a}}$ \\
300 & - & $1.2^{\mathrm{a}}$ & $0.7^{\mathrm{a}}$ \\
900 & $0.5^{\mathrm{a}}$ & $0.6^{\mathrm{b}}$ & $0.8^{\mathrm{a}}$ \\
7,630 (control) & $0.3^{\mathrm{a}}$ & $0.4^{\mathrm{b}}$ & $0.6^{\mathrm{a}}$ \\
\hline
\end{tabular}

Size-class $1=4.5-$ to $9-\mathrm{cm}$ basal diameter and size-class $2=>9 \mathrm{~cm}$ basal diameter.

${ }^{2}$ Basal diameter increment for size-class 1 is not presented by year because there was not a treatment $X$ year interaction $(P>0.1)$.

${ }^{3}$ Basal diameter increment for size-class 2 is presented by year because of a treatment $X$ year interaction $(\mathrm{P}<0.1)$.

No stems in size-class 1 were measured in the 100 and 300 stems ha $^{-1}$ treatments

ab Means within columns with different superscripts are significantly different $(P<0.1)$.

Growth rates of other hardwood species in low-density, intensively-managed stands in semi-arid regions (Knoop and Walker 1985, Meyer and Felker 1990) and more mesic areas are similar to our findings. Smith and Lamson (1983) reported an increase in diameter at $1.3 \mathrm{~m}(\mathrm{dbh})$ of $0.89,1.27$, and $1.35 \mathrm{~cm} \mathrm{year}^{-1}$ for sweet birch (Betula lenta L.), black cherry (Prunus serotina Ehrh.), and yellow poplar (Liriodendron tulipfera L.) respectively, 3 years after pre-commercial thinning of a sapling stand in Pennsylvania. Lamson (1983) reported growth rates of $0.41,0.41$, and $0.96 \mathrm{~cm}_{\text {year }}{ }^{-1}$ for red maple (Acer rebrum $\mathrm{L}$ ), red oak (Quercus rubra L.), and yellow poplar, respectively, 5 years after thinning treatments were applied in the Appalachian region. Growing conditions for mesquite trees on our study site were very favorable for the San Angelo area because soils are deep and fertile. We hypothesize that stem growth rates reported for the 100 and 300 stems ha ${ }^{1}$ treatments in 1992 may represent near- maximum values for mesquite trees in the Edwards Plateau and Rolling Plains resource areas.

\section{Total Wood Production}

Treatment effect on annual wood production of individual stems followed the same pattern as for basal diameter increment because annual wood production by stem was derived from stem diameter. Annual wood production on an area basis was significantly $(\mathrm{P}<0.1)$ lower for the 100,300 , and 900 stems ha $^{-1}$ treatments $(481,1,214$, and $2,439 \mathrm{~kg} \mathrm{ha}^{-1} \mathrm{yr}^{-1}$, respectively) than the control $\left(8,128 \mathrm{~kg} \mathrm{ha}^{-1} \mathrm{yr}^{-1}\right)$. Higher wood production on the control plots compared to the thinned stands was due to the substantially higher stem density for the control $\left(7,630 \text { stems }^{-1}\right)^{-1}$. Total wood production was similar $(\mathrm{P}>0.1)$ among the 100,300 , and 900 stems ha $^{-1}$ treatments. Total wood production was similar $(\mathrm{P}>0.1)$ in 1992 and 1993.

\section{Honey Mesquite Leaf Biomass}

Leaf biomass of mesquite trees was estimated using the regression equation relating basal diameter to foliar biomass. Stems used to develop the regression equation were in a dense stand of mesquite contiguous to the study site. Although the stems in the contiguous stand could be considered representative of stems on the control plots, the relationship between basal diameter and leaf biomass might be different from that for trees growing in naturally occurring sparse stands (e.g., 100 stems ha $^{-1}$ ). It has been documented that individual stems at wider spacings generally produce more wood and foliage than individual stems in denser stands (Schacht et al. 1988, Comejo-Oviedo et al. 1991). The values for leaf biomass presented here, therefore, apply only to this study site and values for the 100 $\left(205 \mathrm{~kg} \mathrm{ha}^{-1}\right), 300\left(1,055 \mathrm{~kg} \mathrm{ha}^{-1}\right)$, and $900\left(1,105 \mathrm{~kg} \mathrm{ha}^{-1}\right)$ stems ha treatments may be underestimated. Honey mesquite leaf biomass for the control $\left(6,875 \mathrm{~kg} \mathrm{ha}^{-1}\right)$ was significantly higher $(\mathrm{P}<0.1)$ than for the thinned treatments, and leaf biomass among the thinned treatments was not different $(P>0.1)$. Although basal diameter tended to be greater for stems on the thinned plots, stem density was the principal factor determining leaf biomass. Total leaf biomass was similar $(P>0.1)$ in 1992 and 1993.

Tree leaf biomass in mesquite woodlands has never been reported because it is very difficult to measure. The small size of leaflets and asynchrony of leaf production and leaf fall make estimation of leaf biomass of a mesquite stand both imprecise and inaccurate. Development of leaf area and (or) canopy volume indices are possible alternatives to the regression equation relating basal diameter to leaf biomass. The leaf biomass estimate for control plots in this study appears to be very high compared to estimates reported for other dry woodland types; however, considering the density of stems, leaf biomass would be about $1 \mathrm{~kg}$ stem $^{-1}$. Leaf biomass estimates in other dry woodlands range from 1,891 and 2,900 kg ha-1 (Collins 1977, Schacht et al. 1988, 1992).

\section{Management Implications}

At the initiation of the study, the herbaceous understory was dominated by low seral, cool-season species, such as Texas wintergrass and rescuegrass. Although they provide valuable coolseason forage, these species have short growing periods, vary greatly in terms of annual forage production, and are unacceptable forage during much of the year. A shift should occur over time to species which are more productive and better adapted to 
the growing conditions in the reduced-canopy treatments. Scifres et al. (1989) hypothesized there was a delay of 4 to 6 years following control of mesquite before herbaceous plant production reached its maximum. The expected shift would involve warmseason grasses largely replacing cool-season grasses because of increased light intensity in reduced-canopy treatments favoring warm-season species (Brock et al. 1978, McDaniels et al. 1978, Jacoby et al. 1982, Heitschmidt and Dowhower 1991). With herbaceous vegetation dominated by warm-season grasses, forage production should be consistently higher and more acceptable to livestock through the grazing season.

Herbaceous plant production for plots with 100 and 300 stems $\mathrm{ha}^{-1}$ was similar to the cleared plots. For thinned treatments, however, these forage responses were realized in addition to 481 to $1,214 \mathrm{hg} \mathrm{ha}^{-1} \mathrm{yr}^{1}$ of wood production by crop trees. Results of our study indicate that mesquite agroforestry systems, with large trees on relatively wide spacings, could provide rapid growth rates of wood and high levels of forage production in the understory, and potentially reduce livestock handling problems associated with dense stands.

Costs for thinning dense stands of mesquite to a desired density, along with follow-up stand management, could be offset largely by the value of harvested, marketable wood. Although an economic analysis was not conducted, it appears that revenue coming from periodic harvest and sale of the widely-spaced crop trees could provide some or all of the funds needed to pay for maintaining a stand with a relatively open canopy. Overall, thinned mesquite woodland has great potential for multiple use management; however, site selection should be a prime consideration. An agroforestry system would be more likely to succeed on range sites with the greatest potential for supporting plant growth. In addition, forage responses should be greatest on sites in high range condition classes.

\section{Literature Cited}

Bedunah, D.J. and R.E. Sosebee. 1984. Forage of a mesquite-buffalograss community following range rehabilitation. J. Range Manage. 37:483-487.

Brock, J.H., R.H. Haas, and J.C. Shaver. 1978. Zonation of herbaceous vegetation associated with honey mesquite in northcentral Texas, p. 187-189. In: D.N. Hyder (ed), Proc. First Int. Rangelands Congr. Soc. Range Manage., Denver, Colo.

Collins, N.M. 1977. Vegetation and litter production in Southern Guinea Savanna, Nigeria. Oecologia 28:163-175.

Cornejo-Oviedo, E., S. Gronski, and P. Felker. 1992. Mature mesquite (Prosopis glandulosa var. glandulosa) stand description and preliminary effects of understory removal and fertilization on growth. J. Arid Environ. 22:339-351.

Cornejo-Oviedo, E.H., J.M. Meyer, and P. Felker. 1991. Thinning dense sapling stands of mesquite (Prosopis glandulosa var. glandulosa) to optimize timber production and pasture improvement. Forest. Ecol. and Manage. 46:189-200.

Dahl, B.E., R.E. Sosebee, J.P. Goen, and C.S. Brumley. 1978. Will mesquite control with 2,4,5-T enhance grass production? J. Range Manage. 31:129-131.

Dugas, W.A. and H.S. Mayuex. 1991. Evaporation from rangeland with and without honey mesquite. J. Range Manage. 44:161-171.

Felker, P., J.M. Meyer, and S.J. Gronski. 1990. Application of selfthinning in mesquite (Prosopis glandulosa var. glandulosa) to range management and lumber production. Forest. Ecol. and Manage. 31:225-232.
Gibbens, R.P., C.H. Herbel, H.L. Morton, W.C. Lindemann, J.A. Ryder-White, D.B. Richman, E.W. Huddleston, W.H. Conley, C.A. Davis, J.A. Reitzel, D.M. Anderson, and A. Guiao. 1986. Some impacts of 2,4,5-T on a mesquite duneland ecosystem in southern New Mexico: a synthesis. J. Range Manage. 39:320-325.

Heilschmidt, R.K. and S.L. Dowhower. 1991. Herbage response following control of honey mesquite within single tree lysimeters. J. Range Manage. 44:144-149.

Heitschmidt, R.K., K.J. Ansley, S.L. Dowhower, P.W. Jacoby, and D.L. Price. 1988. Some observations from the excavation of honey mesquite root systems. J. Range Manage. 41:227-231.

Jacoby, P.W., C.H. Meadors, M.A. Foster, and F.S. Hartmann. 1982. Honey mesquite control and forage response in Crane County, Texas. I. Range Manage. 35:424-426.

Knoop, W.T. and B.H. Walker. 1985. Interactions of woody and herbaceous vegetation in a southern African savanna. J. Ecol. 72:235-253.

Lamson, N.I. 1983. Precommercial thinning increases diameter growth of Appalachian hardwood stump sprouts. J. Appl. For. 7:93-97.

McDaniels, K.C., R.H. Haas, and J.H. Brock. 1978. Range condition trends following control of honey mesquite (Prosopis glandulosa var. glandulosa) on deep hardlands in northcentral Texas, p. 530-533. In: D.N. Hyder (ed), Proc. First Int. Rangeland Congr., Soc. Range Manage., Denver, Colo.

McPherson, G.R. and H.A. Wright. 1986. Threshold requirements for burning downed honey mesquite. J. Range Manage. 39:327-330.

Meyer, J.M. and P. Felker. 1990. Pruning mesquite (Prosopis glandulosa var. glandulosa) saplings for lumber production and ornamental use. Forest. Ecol. Manage. 36:301-306.

SAS Institute Inc. 1988. SAS/STAT User's Guide, 6.03 edition. SAS Institute Inc., Cary, N.C.

Scifres, C.J. 1980. Brush management: Principles and practices for Texas and the Southwest. Texas A\&M University Press. College Station, Tex.

Scifres, C.J. and D.B. Polk, Jr. 1974. Vegetation response following spraying a light infestation of honey mesquite. J. Range Manage. 27:426-465.

Scifres, C.J., B.H. Koerth, R.A. Crane, R.C. Flinn, W.T. Hamilton, T.G. Welch, D.N. Ueckert, C.W. Hanselka, and L.D. White. 1989. Management of south Texas mixed brush with herbicides. Texas Agr. Exp. Sta. Bull. B-1623. College Station, Tex.

Schacht, W.H., J.N. Long, and A. Gobena. 1992. Above-ground biomass accumulation in coppicing woodland, northeast Brazil. Forest. Ecol. and Manage. 55:201-208.

Schacht, W.H., J.N. Long, and J.C. Malechek. 1988. Above-ground production in cleared and thinned stands of semi-arid tropical woodland, Brazil. Forest. Ecol. and Manage. 23:201-214.

Smith, H.C. and N.I. Lamson. 1983. Pre-commercial crop-tree release increases diameter growth of Appalachian hardwood saplings. U.S. Dept. Agr. Forest. Serv. Res. Pap. NE-534, Broomall, Penn., 7 pp.

Steel, R.G.D. and J.H. Torrie. 1980. Principles and procedures of statistics. McGraw-Hill Co. Inc., N.Y.

Weltzin, J.F. 1990. The potential role of prairie dogs in regulating honey mesquite population dynamics. M.S. Thesis, Texas A\&M University, College Station, Tex.

Wiedenfeld, C.C. and P.H. Flores. 1976. Soil survey of Tom Green County, Texas. National Cooperative Soil Survey. Washington, D.C.

Winer, B.V. 1971. Statistical principles in experimental design. McGraw-Hill, N.Y.

USDA. 1989. Soil survey of Tom Green County, Texas. USDA, Washington, D.C. 